\title{
Collaborative supply chain: a conceptual model for operationalisation
}

\author{
Angela Cristina Marqui* \\ dot.rural, \\ RCUK Digital Economy Research, \\ University of Aberdeen, \\ Room 829 MacRobert Building, \\ King's College, Aberdeen AB24 5UA, UK \\ E-mail: acmarqui@gmail.com \\ *Corresponding author
}

\section{Karina Sacilotto de Moura and \\ Rosane Lucia Chicarelli Alcântara}

\author{
Department of Production Engineering, \\ Federal University of São Carlos, \\ Rodovia Washington Luiz, km 235, Caixa Postal 676, \\ São Carlos, CEP: 13.565.905, São Paulo, Brazil \\ E-mail: karina_sacilotto@yahoo.com.br \\ E-mail: rosane@dep.ufscar.br
}

\begin{abstract}
The aim of this study was to develop a conceptual model for establishing cooperation, coordination and collaboration in supply chains. The literature review revealed: 1) nine characteristics that the relationship among companies developing collaboration in the supply chain should embody; 2) ten behaviours that companies developing collaboration in the supply chain should adopt. The characteristics and behaviours were employed in order to design a conceptual model, which is developed as a ladder of three major steps. The first step consists of characteristics and behaviours required for a cooperative relationship. The second step comprises the requirements for coordination. The third and final step displays the characteristics and behaviours enablers of collaborative practices in supply chains.
\end{abstract}

Keywords: supply chain; collaboration; coordination; cooperation; collaborative supply chain; conceptual model; collaborative behaviour; relationships; literature review; integration.

Biographical notes: Angela Cristina Marqui is a Research Fellow in Logistics and Transport at University of Aberdeen. She received her PhD in Production Engineering from Federal University of São Carlos and MSc in Business from University of São Paulo. 
Karina Sacilotto de Moura is an MSc student in the Production Engineering Department at Federal University of São Carlos. Her research interest is in the area of supply chain collaboration, focusing on agro-industrial context.

Rosane Lucia Chicarelli Alcântara is an Associate Professor at Federal University of São Carlos. She received her Bachelor in Production Engineering (1985) from Federal University of São Carlos, her MSc (1992) and her PhD (1997) both in Business from Getúlio Vargas Foundation Business School (São Paulo/Brazil). Her research interests include distribution channels, supply chain management and business logistics.

\section{Introduction}

A collaborative supply chain consists of two or more independent companies working together to plan and execute supply chain operations with greater success than when performing the same activities individually (Simatupang and Sridharan, 2002). Collaboration is more than just the exchange of information at an operational level; it also requires the involvement of tactical and strategic levels across the companies (Barratt, 2004a). Besides this, the availability of modern information technologies (IT) has become an enabler of collaborative relationships within the supply chain. Nevertheless, for Mentzer et al. (2000), collaboration is far more complex than a set of techniques and systems. A number of attitudes (or behaviours) and skills are required in order to make the collaborative supply chain a reality. This paper does not address the IT requirements for establishing collaborative supply chains; rather, it focuses on characteristics and behaviours of companies within collaborative supply chains.

Organisations are encouraged to collaborate in order to gain access to resources needed for their operations, to learn and develop new skills, to manage their dependence on other firms with which they do business and/or to maintain parity with other competitors (Ahuja, 2000). It is worth mentioning that an organisation can adopt a collaborative attitude with both their suppliers and their customers, noting that, in order to expand the customers base, their suppliers must support them (Singh and Power, 2009). On the other hand, companies should not collaborate with everybody, rather, companies should focus their attention on a small number of close relationships, which will probably be with strategically important customers and suppliers (Barratt, 2004a).

The fact that companies should collaborate only with a small number of strategic partners does not mean that all other relationships will be, or should be, transactional or at an arms-length. Mentzer et al. (2000) consider that a company must adopt different types of relationships with different companies in the supply chain, according to their needs and available resources. Besides this, there is little consensus regarding what characterises a collaborative relationship and how companies engaged in practices requiring different levels of integration are expected to behave.

In this paper we propose a conceptual model for establishing cooperation, coordination and collaboration in supply chains. The remainder of this paper is organised as follows: firstly, it provides a review and analysis of the definition of collaboration, coordination and cooperation; secondly, based on the literature related to collaboration, it shows the characteristics and behaviours of collaborative supply chains; thirdly, we establish a conceptual model for establishing cooperation, coordination and collaboration 
in supply chains; finally, contributions, limitations and conclusions of this study are outlined.

\section{Levels of integration}

Several authors classify the types of relationships between companies in a supply chain (Spekman et al., 1998; Camarinha-Matos and Afsarmanesh, 2006; Bäckstrand, 2007). Even though such classifications vary from author to author, there is a consensus that, when focusing on relationships between two or more companies, the highest level of integration is collaboration. On the other hand, there is confusion and ambiguity about what cooperation and coordination means, and whether cooperation means a higher level of integration than coordination or the other way around. These two terms have been misused as synonyms, what can lead to confusion (Moharana et al., 2012). In this section, firstly, we clarify the definitions for these three terms and then we analyse a sample of classifications of types of relationships among companies in the supply chain. Table 1 presents the definitions of cooperation, coordination and collaboration selected from the literature.

Table 1 Selected definitions of cooperation, coordination and collaboration

\begin{tabular}{|c|c|}
\hline Authors & Definition \\
\hline \multicolumn{2}{|r|}{ Cooperation } \\
\hline $\begin{array}{l}\text { Spekman et al. } \\
\text { (1998) }\end{array}$ & $\begin{array}{l}\text { By means of cooperation, companies exchange essential information and } \\
\text { establish long-term contracts with some suppliers/customers. }\end{array}$ \\
\hline $\begin{array}{l}\text { Camarinha-Matos } \\
\text { and Afsarmanesh } \\
(2006)\end{array}$ & $\begin{array}{l}\text { It involves information exchange and adjustments of activities, sharing } \\
\text { resources for achieving compatible goals in the sense that the results of } \\
\text { individual organisations can be added or composed in a value chain leading } \\
\text { to the final product or service. There is a common plan, which in most cases } \\
\text { is not defined jointly, but rather designed by a single entity. The participants } \\
\text { work in a quasi-independent manner and low-level co-working is required. }\end{array}$ \\
\hline $\begin{array}{l}\text { Moharana et al. } \\
(2012)\end{array}$ & $\begin{array}{l}\text { Cooperation is defined as acting or working together for a shared purpose, } \\
\text { toward a common end or goal, and being compliant. The notion of 'working } \\
\text { together' in the context of cooperation does not suggest a close operational } \\
\text { working relationship, but rather a positive attitude towards each other. }\end{array}$ \\
\hline \multicolumn{2}{|r|}{ Coordination } \\
\hline $\begin{array}{l}\text { Spekman et al. } \\
\text { (1998) }\end{array}$ & $\begin{array}{l}\text { By means of coordination, companies exchange both specified workflow and } \\
\text { information in a way that allows the implementation of coordination systems } \\
\text { designed for continuous flow of information between and among trading } \\
\text { parties, such as just in time (JIT), electronic data interchange (EDI). }\end{array}$ \\
\hline $\begin{array}{l}\text { Camarinha-Matos } \\
\text { and Afsarmanesh } \\
(2006)\end{array}$ & $\begin{array}{l}\text { Coordination is the act of working together harmoniously. It involves } \\
\text { communication, information sharing and aligning/altering activities to } \\
\text { achieve more efficient. Nevertheless, each entity might have a different goal } \\
\text { and uses its own resources and methods of impact creation; value is mostly } \\
\text { created at individual level. }\end{array}$ \\
\hline $\begin{array}{l}\text { Moharana et al. } \\
(2012)\end{array}$ & $\begin{array}{l}\text { Coordination is 'the act of making arrangements for a purpose', 'harmonious } \\
\text { adjustments of interaction', and making separate things working together. } \\
\text { Coordination indicates an interactive, joint decision making process, where } \\
\text { separate entities influence each other's decision more directly. It refers to a } \\
\text { more direct and active relationship than in cooperation. }\end{array}$ \\
\hline
\end{tabular}


Table 1 Selected definitions of cooperation, coordination and collaboration (continued)

\begin{tabular}{ll}
\hline Authors & Definition \\
\hline $\begin{array}{l}\text { Spekman et al. } \\
(1998)\end{array}$ & $\begin{array}{l}\text { Collaboration requires high levels of trust, commitment, and information } \\
\text { sharing among supply chain partners. It also requires a shared and common } \\
\text { vision of the future in a way that future design and product performance, } \\
\text { and long-term strategic intentions are shared. In a collaborative relationship, } \\
\text { partners are engaged in joint planning and processes beyond levels reached in }\end{array}$ \\
less intense trading relationships.
\end{tabular}

From Table 1, it can be seen why there is some confusion when discussing these concepts. For example, Camarinha-Matos and Afsarmanesh (2006) consider that cooperation requires a higher level of integration than coordination; therefore, the definition of coordination presented by these authors is similar to what Moharana et al. (2012) and Spekman et al. (1998) mean by cooperation. Apart from this, there is, to certain extent, agreement on the increasing level of integration among supply chain members, from a transactional behaviour to a collaborative supply chain. Table 2 summarises how different authors classify the levels of integration required in each of these three types of relationship.

Table 2 Levels of integration in the supply chain

\begin{tabular}{lc}
\hline Authors & From lower to higher level of integration in the supply chain \\
\hline Spekman et al. (1998) & $\begin{array}{c}\text { Open market negotiations } \rightarrow \text { cooperation } \rightarrow \\
\text { coordination } \rightarrow \text { collaboration }\end{array}$ \\
$\begin{array}{l}\text { Camarinha-Matos and } \\
\text { Afsarmanesh (2006) }\end{array}$ & Network $\rightarrow$ coordination $\rightarrow$ cooperation $\rightarrow$ collaboration \\
Bäckstrand (2007) & Single transaction $\rightarrow$ arms-length $\rightarrow$ adversarial $\rightarrow$ partnership \\
Moharana et al. (2012) & Cooperation $\rightarrow$ coordination $\rightarrow$ collaboration \\
\hline
\end{tabular}

As previously mentioned, Spekman et al. (1998) and Moharana et al. (2012) view coordination as a higher level of integration among the organisations than cooperation. Finally, Bäckstrand (2007) proposes a two-stage classification for describing the intensity of integration among companies. The first stage consists of transactional and collaborative relationships. The transactional phase, which typically consists of trade negotiations based on price, is divided into single transaction being the lowest level of interaction, and arms-length being also transactional, but characterised by a more intense level of interaction. The collaboration phase is divided into adversarial and partnership. It is worth noting that Bäckstrand (2007) used the term interaction instead of integration. The author considers that interaction is the relationship among companies, and 
integration occurs when there is incorporation of two entities shaping a single organisation.

Spekman et al. (1998) explain that the transition from open market negotiations to collaboration requires behavioural changes and, even, changes in strategic orientation. Cooperation and coordination are early stages towards a collaborative relationship, and this transition is a long process in which companies must select carefully their potential partners (Spekman et al., 1998). As a company moves from a transactional behaviour to a collaborative one, the commitment among the involved entities increases, as well as joint investment in resources and capabilities.

We adopt the definitions presented by Spekman et al. (1998), which we consider to set more specifically the distinction among each of the terms. Regarding the classification of level of integration, we agree with Moharana et al. (2012) and Spekman et al. (1998), in which the first level of integration is cooperation, then coordination, and collaboration being the highest level of integration in the supply chain.

This paper focuses on the process of integration between companies expressing willingness to work together. Therefore, our focus will be on cooperation, coordination and collaboration. This excludes two extremes; the transactional end, also named open market negotiations, and the vertical integration of companies. In the transactional end, companies are choosing to not develop closer relationships with customers and/or suppliers. At the other end, integration into a single entity, as expressed by Bäckstrand (2007), means vertical integration, acquisition or joint venture, which is also beyond the scope of this study.

From the definitions of cooperation, coordination and collaboration in supply chains presented in Table 1, and taking into consideration that we have adopted the classification of level of integration proposed by Moharana et al. (2012) and Spekman et al. (1998), the constructs that underpin each of these definitions are presented in Table 3.

Table 3 Constructs that underpin the definitions of cooperation, coordination and collaboration

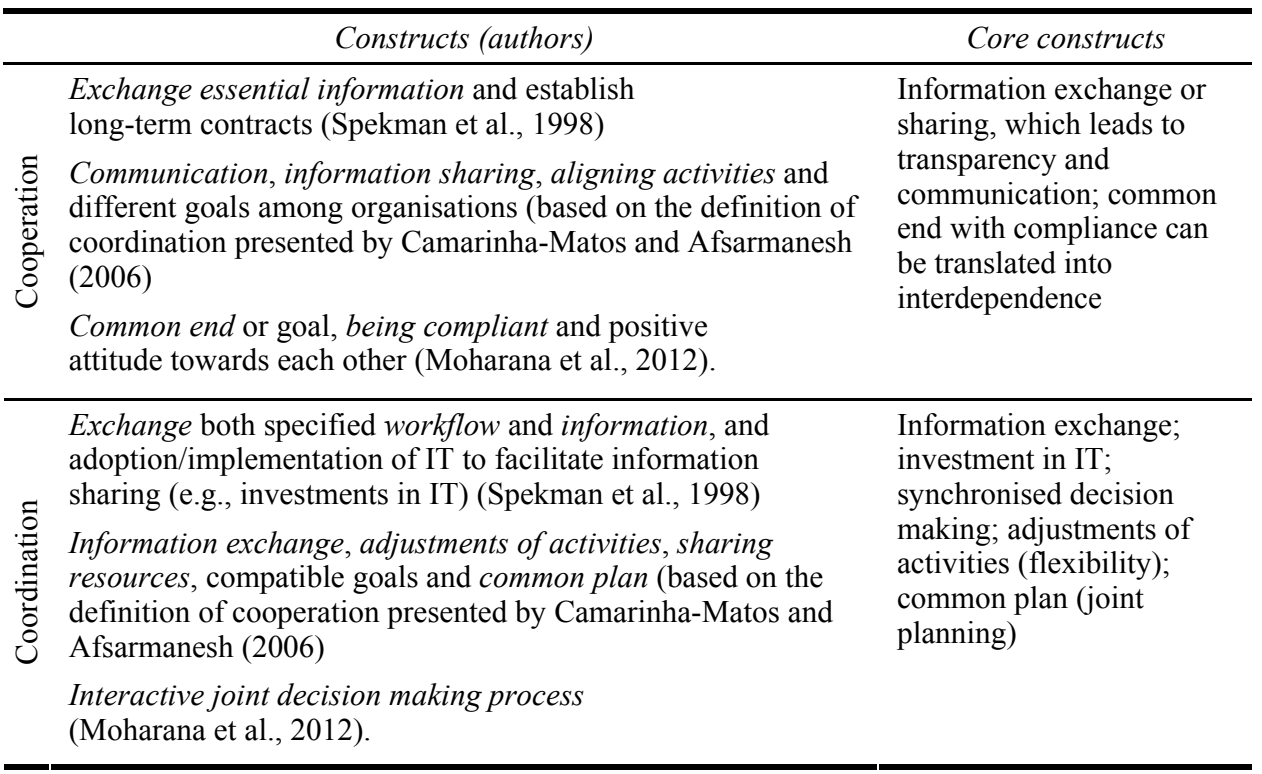


Table 3 Constructs that underpin the definitions of cooperation, coordination and collaboration (continued)

\begin{tabular}{ll}
\hline \multicolumn{1}{c}{ Constructs (authors) } & \multicolumn{1}{c}{ Core constructs } \\
\hline $\begin{array}{l}\text { High levels of trust, commitment } \text { and information sharing, } \\
\text { shared common vision of the future, long-term strategic } \\
\text { intentions and joint planning (Spekman et al., 1998) }\end{array}$ & $\begin{array}{l}\text { All the above plus: } \\
\text { trust; commitment; } \\
\text { mutual engagement; } \\
\text { long-term relationship; } \\
\text { common goals; }\end{array}$ \\
joint performance \\
measurement.
\end{tabular}

We italicised the constructs comprised in the definitions from the literature, which we grouped in core constructs. In some cases, the core construct is a result or a rewording of the constructs underlined. The core constructs will be the basis for understanding what is required in order to establish such relationships with members of a supply chain. Having evidenced some of the constructs from the definitions presented from the literature, and knowing that collaboration is the highest level of integration, the next section explore a sample of the literature regarding collaboration in order to identify other constructs that may be relevant to this discussion.

\section{Characteristics and behaviours required for collaborative relationships}

Cooperating with and coordinating operations with strategically selected partners is the way to achieve collaboration within the supply chain. However, cooperation is a necessary, but not sufficient condition to achieve coordination, with coordination being a necessary, but not sufficient condition to achieve collaboration. By clarifying the importance of establishing and maintaining the cooperation, followed by coordination as a prerequisite for collaboration, we expect to contribute to companies' decision making process, as to whether they should or not invest time and effort on developing a collaborative relationship.

In order to support this decision making process, we identified from the literature:

1 the main characteristics that the relationship among companies developing collaboration in the supply chain should embody

2 the main behaviours that companies developing collaboration in the supply chain should adopt, which are shown in Table 4 and Table 5 respectively.

The characteristics refer to a mindset that companies aiming to engage in collaborative practices should embody. The behaviours refer to actions that companies will need to perform in order to implement collaborative practices, and potentially achieve the benefits of collaboration. 
Table 4 Main characteristics required for collaborative relationship in supply chains

\begin{tabular}{|c|c|c|c|c|c|c|c|c|c|}
\hline \multirow[b]{2}{*}{ Authors } & \multicolumn{9}{|c|}{ Characteristics } \\
\hline & 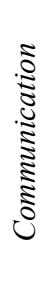 & 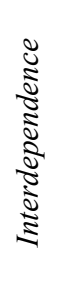 & 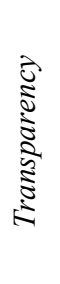 & 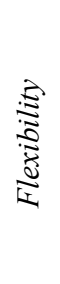 & 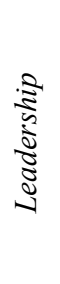 & 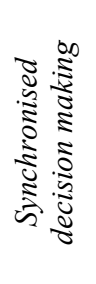 & 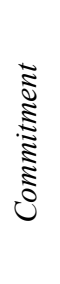 & 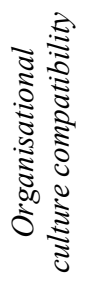 & $\frac{\overleftarrow{3}}{5}$ \\
\hline Tjosvold (1988) & & $\mathrm{x}$ & & & & & & & \\
\hline Kumar and VanDiesel (1996) & & $\mathrm{x}$ & & & & & & $\mathrm{x}$ & $\mathrm{x}$ \\
\hline Dyer (1997) & & & & & & & $\mathrm{x}$ & & $\mathrm{x}$ \\
\hline Mentzer et al. (2000) & & $\mathrm{x}$ & & & $\mathrm{x}$ & & $\mathrm{x}$ & & $\mathrm{x}$ \\
\hline Stank et al. (2001) & $\mathrm{x}$ & & & $\mathrm{x}$ & & & $\mathrm{x}$ & & $\mathrm{x}$ \\
\hline Handfield and Bechtel (2002) & $\mathrm{x}$ & $\mathrm{x}$ & & & & & & & $\mathrm{x}$ \\
\hline Akkermans and VanDoremalen (2004) & & & $\mathrm{x}$ & & & & & & $\mathrm{x}$ \\
\hline Barratt (2004a) & $\mathrm{x}$ & $\mathrm{x}$ & $\mathrm{x}$ & $\mathrm{x}$ & & & $\mathrm{x}$ & & $\mathrm{x}$ \\
\hline Barratt (2004b) & $\mathrm{x}$ & $\mathrm{x}$ & $\mathrm{x}$ & & & & $\mathrm{x}$ & & $\mathrm{x}$ \\
\hline Chen and Paulraj (2004) & & & & & & & $\mathrm{x}$ & & $\mathrm{x}$ \\
\hline Möller and Svahn (2004) & & & & & & & & $\mathrm{x}$ & \\
\hline Pitsis et al. (2004) & $\mathrm{x}$ & & $\mathrm{x}$ & & $\mathrm{x}$ & & & $\mathrm{x}$ & $\mathrm{x}$ \\
\hline Cadilhon et al. (2005) & & & & & & & & $\mathrm{x}$ & \\
\hline Min et al. (2005) & & & & & & $\mathrm{x}$ & & & \\
\hline Myhr and Spekman (2005) & $\mathrm{x}$ & & & & & & & & $\mathrm{x}$ \\
\hline Simatupang and Sridharan (2005) & & $\mathrm{x}$ & & & & $\mathrm{x}$ & & & \\
\hline Fawcett et al. (2006) & & & & & & & $\mathrm{x}$ & & \\
\hline Fearne et al. (2006) & & & & $\mathrm{x}$ & & & & & \\
\hline Sheu et al. (2006) & $\mathrm{x}$ & $\mathrm{x}$ & & & & $\mathrm{x}$ & & & $\mathrm{x}$ \\
\hline Danese (2007) & $\mathrm{x}$ & & & & & $\mathrm{x}$ & & & \\
\hline Matopoulos et al. (2007) & & $\mathrm{x}$ & & & & & & $\mathrm{x}$ & \\
\hline Pigatto and Alcantara (2007) & $\mathrm{x}$ & $\mathrm{x}$ & & $\mathrm{x}$ & & & $\mathrm{x}$ & $\mathrm{x}$ & $\mathrm{x}$ \\
\hline Smith et al. (2007) & & & & & & $\mathrm{x}$ & & & \\
\hline Fawcett et al. (2008) & & & & & & & & & $\mathrm{x}$ \\
\hline Simatupang and Sridharan (2008) & & & & & & $\mathrm{x}$ & & & \\
\hline Singh and Power (2009) & & $\mathrm{x}$ & & & & & & & \\
\hline Squire et al. (2009) & & & & $\mathrm{x}$ & & & & & \\
\hline Vieira et al. (2009a) & & $\mathrm{x}$ & & $\mathrm{x}$ & & & & & $\mathrm{x}$ \\
\hline Vieira et al. (2009b) & & $\mathrm{x}$ & & $\mathrm{x}$ & & & & & $\mathrm{x}$ \\
\hline Esper et al. (2010) & & $\mathrm{x}$ & & & & & & & \\
\hline
\end{tabular}

Note: ' $\mathrm{x}$ ' is included when the characteristics are mentioned in the literature consulted. 
Table 4 Main characteristics required for collaborative relationship in supply chains (continued)

\begin{tabular}{|c|c|c|c|c|c|c|c|c|c|}
\hline \multirow[b]{2}{*}{ Authors } & \multicolumn{9}{|c|}{ Characteristics } \\
\hline & 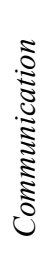 & 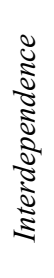 & 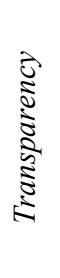 & 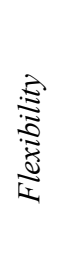 & 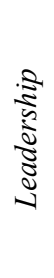 & 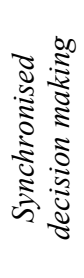 & 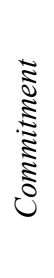 & 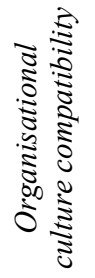 & $\frac{\tilde{s}}{5}$ \\
\hline Fawcett et al. (2010) & & & $\mathrm{x}$ & & & & & & \\
\hline Hammervoll and Bø (2010) & $\mathrm{x}$ & & $\mathrm{x}$ & & & $\mathrm{x}$ & & & $\mathrm{x}$ \\
\hline Kim and Lee (2010) & $\mathrm{x}$ & & & & & & & & \\
\hline Olorunniwo and $\mathrm{Li}$ (2010) & & $\mathrm{x}$ & & & & & & & $\mathrm{x}$ \\
\hline Vieira et al. (2010a) & & $\mathrm{x}$ & & $\mathrm{x}$ & & & & & $\mathrm{x}$ \\
\hline Vieira et al. (2010b) & & $\mathrm{x}$ & $\mathrm{x}$ & $\mathrm{x}$ & & & & & $\mathrm{x}$ \\
\hline Braziotis and Tannock (2011) & $\mathrm{x}$ & & & & & & $\mathrm{x}$ & $\mathrm{x}$ & $\mathrm{x}$ \\
\hline Cao and Zhang (2011) & $\mathrm{x}$ & & & $\mathrm{x}$ & & & $\mathrm{x}$ & & \\
\hline Danese (2011) & $\mathrm{x}$ & & & & & & $\mathrm{x}$ & & \\
\hline Lee et al. (2011) & & & & & & & & & $\mathrm{x}$ \\
\hline Lehoux et al. (2011) & & & & & & & $\mathrm{x}$ & & \\
\hline Piriyakul (2011) & $\mathrm{x}$ & $\mathrm{x}$ & & & & & & & $\mathrm{x}$ \\
\hline
\end{tabular}

Note: ' $\mathrm{x}$ ' is included when the characteristics are mentioned in the literature consulted.

Table 5 Main behaviours required for a collaborative supply chain

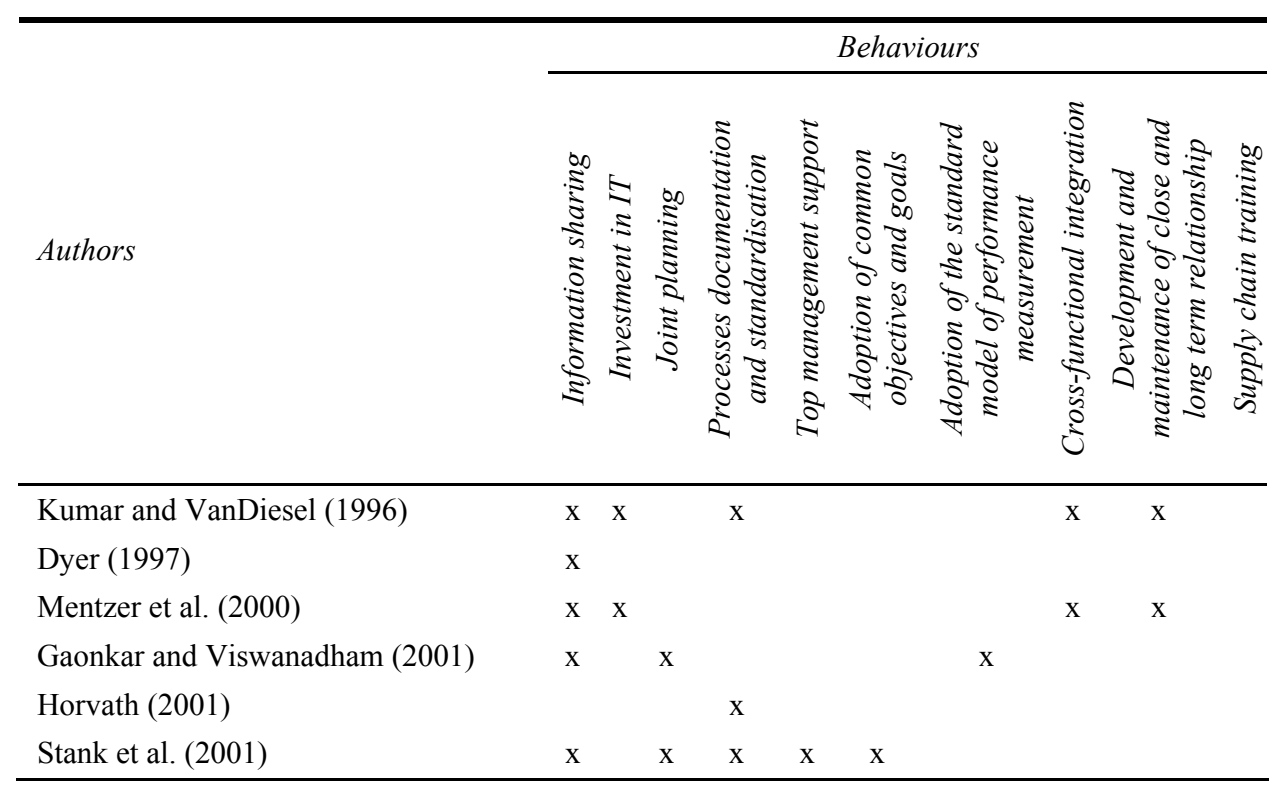

Note: ' $x$ ' is included when the behaviours are mentioned in the literature consulted. 


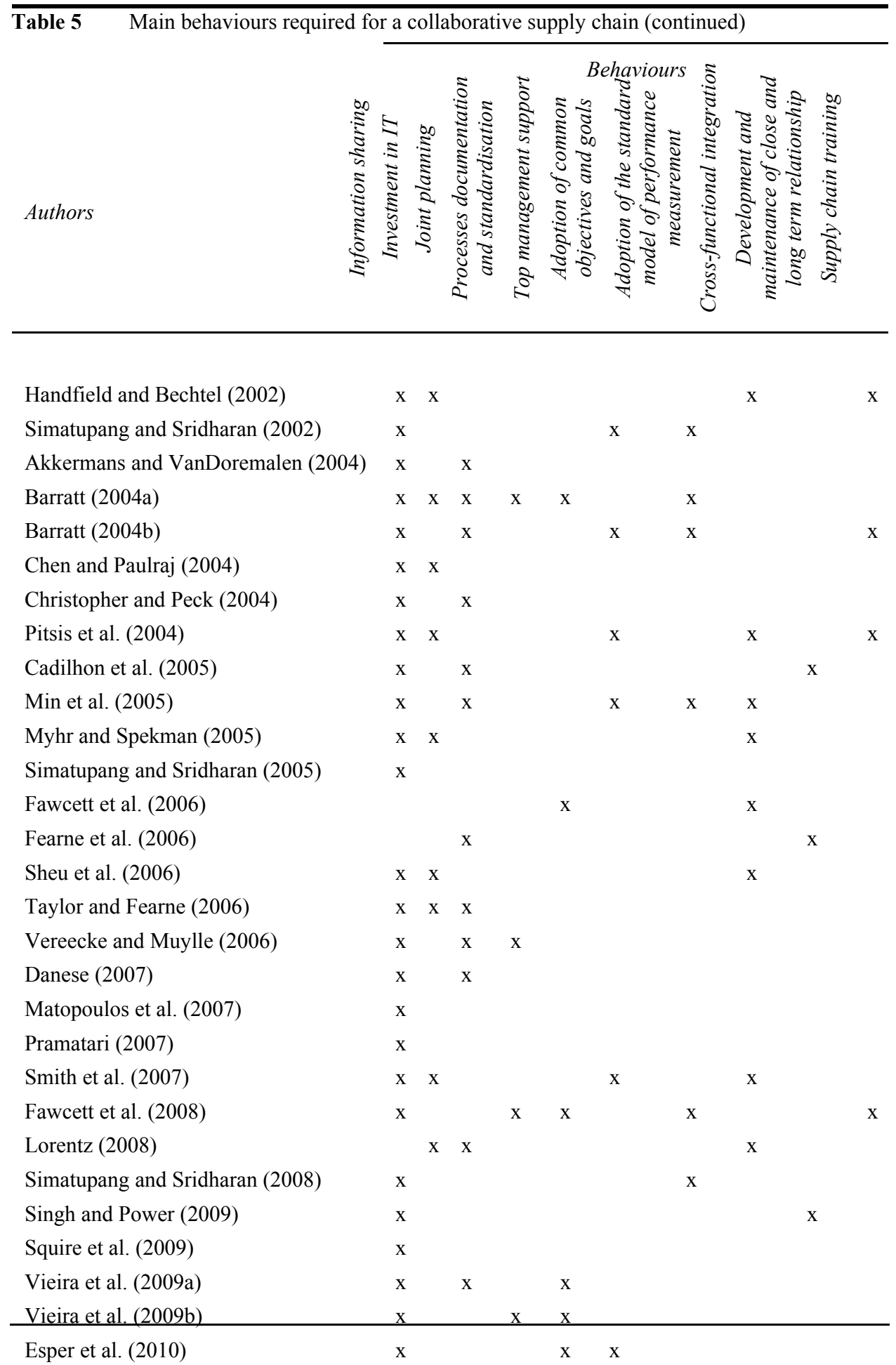

Note: ' $\mathrm{x}$ ' is included when the behaviours are mentioned in the literature consulted. 
Table 5 Main behaviours required for a collaborative supply chain (continued)

\begin{tabular}{|c|c|c|c|c|c|c|c|c|c|c|}
\hline \multirow[b]{2}{*}{ Authors } & \multicolumn{10}{|c|}{ Behaviours } \\
\hline & 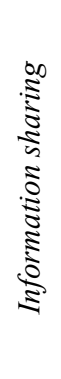 & 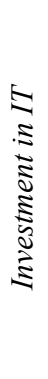 & 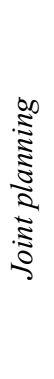 & 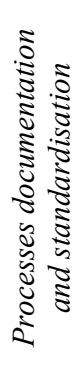 & 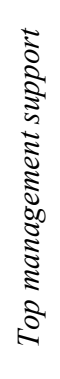 & 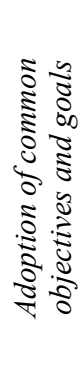 & 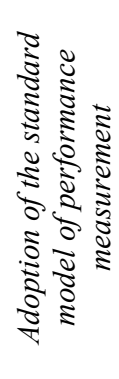 & 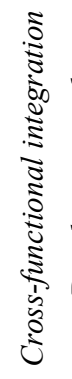 & 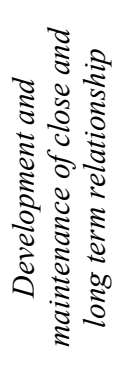 & 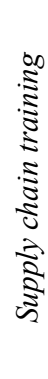 \\
\hline Fawcett et al. (2010) & $\mathrm{x}$ & $\mathrm{x}$ & & & & $\mathrm{x}$ & $\mathrm{x}$ & $\mathrm{x}$ & & $\mathrm{x}$ \\
\hline Hammervoll and Bø (2010) & $\mathrm{x}$ & & & & & & & & & \\
\hline Kim and Lee (2010) & $\mathrm{x}$ & & $\mathrm{x}$ & & & $\mathrm{x}$ & $\mathrm{x}$ & & & \\
\hline Olorunniwo and $\mathrm{Li}$ (2010) & $\mathrm{x}$ & & $\mathrm{x}$ & & & $\mathrm{x}$ & $\mathrm{x}$ & & & \\
\hline Vieira et al. (2010a) & $\mathrm{x}$ & & & & & & & & & \\
\hline Vieira et al. $(2010 b)$ & $\mathrm{x}$ & & & & $\mathrm{x}$ & & & & & \\
\hline Braziotis and Tannock (2011) & $\mathrm{x}$ & $\mathrm{x}$ & & & & & & $\mathrm{x}$ & & \\
\hline Danese (2011) & $\mathrm{x}$ & & $\mathrm{x}$ & & & & & & & \\
\hline Lee et al. (2011) & $\mathrm{x}$ & & & & & & & & $\mathrm{x}$ & \\
\hline Lehoux et al. (2011) & $\mathrm{x}$ & $\mathrm{x}$ & $\mathrm{x}$ & & & & & $\mathrm{x}$ & $\mathrm{x}$ & \\
\hline Piriyakul (2011) & $\mathrm{x}$ & & & & & & & & & \\
\hline Yer (2011) & & $\mathrm{x}$ & $\mathrm{x}$ & & & & & & & \\
\hline
\end{tabular}

Note: ' $\mathrm{x}$ ' is included when the behaviours are mentioned in the literature consulted.

Regarding the nine characteristics and ten behaviours listed in Table 4 and Table 5, these are required for a collaborative relationship within the supply chain, which is the highest and most demanding level of integration discussed in Section 2. Later in this paper, we discuss the characteristics and behaviours required for establishing cooperation and coordination. Each of the characteristics and behaviours are now explained in detail.

\section{Characteristics of collaborative relationships}

\subsection{Communication}

Communication refers to all forms of information exchange, including informal communication, that takes place within the collaborative relationship (Pitsis et al., 2004). Supply chain members should identify the channels of communication that will be used to communicate within the company and between companies, giving equal importance to intra and inter-organisational communication (Barratt, 2004b). An early communication, showing proactive behaviour, in cases of potential problems is also recommended when developing a closer relationship 


\subsection{Interdependence}

Interdependence, also known as mutual dependence, refers to the dependence of a member on some knowledge that belongs to a supply chain partner and vice versa in order to achieve mutual benefits in an interactive process (Vieira et al., 2009a). This relationship of mutual dependence between supply chain members includes issues such as risks, rewards and losses sharing (Barratt, 2004a). In an intra-organisational environment, individuals exchange resources and manage conflicts in order to achieve collective goals and build a supportive community (Tjosvold, 1988).

\subsection{Transparency}

Transparency in the communication channels used among companies is crucial in order to enhance collaboration among supply chain members (Pitsis et al., 2004). Transparency in the context of collaborative relationships means communication with parties when a problem or potential disruption in the supply chain activities is identified is immediate (Barratt, 2004b). Fawcett et al. (2010) highlight the importance of all the members using one single and transparent channel of communication, in order to guide the relationship along the supply chain.

\subsection{Flexibility}

Flexibility is the ability to change/respond to new circumstances; it is related to the degree of change required for building and maintaining collaborative behaviour among supply chain members (Vieira et al., 2009a). The development of collaborative relationships requires behavioural changes, such as from traditional adversarial attitudes to a perspective that encourages cooperation and free exchange of information (Stank et al., 2001).

\subsection{Leadership}

Leadership is a key factor to ensure that pivotal tasks are completed accurately, on time, and in accordance with the agreed specifications (Pitsis et al., 2004). In other words, the authors emphasise the vital role of a leading team to manage the collaborative initiatives. Mentzer et al. (2000) reinforce that there must be a leading figure with power or sufficient reputation to command the involved parties in the collaboration.

\subsection{Synchronised decision-making}

Synchronised decision-making refers to decisions made jointly by the members of the supply chain, both in the tactical and operational levels (Simatupang and Sridharan, 2005). In the tactical level, decisions related to issues such as market segmentation, product variety, level of customer service, promotions and forecasts should be synchronised. On the other hand, the operational level is concerned with order fulfilment, from receiving the order to delivering it to the customer. 


\subsection{Commitment}

Commitment implies that the organisations involved in the relationship are willing to commit effort and resources in order to support the relationship and achieve the supply chain goals (Chen and Paulraj, 2004). The idea of commitment must be disseminated both within the company and among the organisations involved in the relationship (Fawcett et al., 2006). Commitment can be established based on good interpersonal relationship, concession of mutual benefits, trust and successful pilot programmes (Fawcett et al., 2006).

\subsection{Organisational culture compatibility}

Some level of organisational compatibility is essential for the success of collaborative relationships. Organisational culture is related to the way the organisation is structured, which may provide conditions for a collaborative relationship to occur. For example, individuals who are used to an individualist culture are more likely to motivate themselves with personal goals; on the other hand, those adapted to a collectivist culture are more likely to work better with team goals and rewards (Möller and Svahn, 2004).

\subsection{Trust}

Trust relates to the belief that supply chain partners will act in a consistent way according to what they had anticipated (Chen and Paulraj, 2004). On the one hand, trust is an essential element for the development and maintenance of collaborative relationships among supply chain members. On the other hand, Pitsis et al. (2004) explain that trust in excess can lead to credulous behaviour towards the supply chain partners. Therefore, the authors suggest that some sceptical behaviour is indeed needed, particularly in the early stages of a partnership or when some of the members have shown dubious behaviour. Kumar and VanDiesel (1996) justify that any opportunistic behaviour in the short term will probably increase the level of mistrust between the partners and, consequently it is essential that potential risks are identified in advance, in order to avoid future conflicts.

\section{Behaviour for a collaborative relationship}

\subsection{Information sharing}

Information sharing allows each member of the supply chain to capture, store and provide the information necessary to aid the decision making process (Simatupang and Sridharan, 2002). Thus, thought information sharing members gain greater visibility to monitor and track the progress of the products along the supply chain (Simatupang and Sridharan, 2008). One of the key priorities for risk reduction in the chain is associated with the ability of partners to exchange information among the members (Christopher and Peck, 2004). Another important aspect is the creation of a single point of contact between members. The presence of intermediaries in communication may, for example, represent a potential barrier to transparency along the chain, resulting thus in asymmetric information (Barratt, 2004a). 


\subsection{Investment in information technology}

The use of information technology is seen as a facilitator of collaboration (Yer, 2011). On the other hand, this does not necessarily mean investment in high technology (Barratt, 2004a). This is because small companies operating within the supply chain may not have financial resources in order to make significant investments (Taylor and Fearne, 2006).

An interconnected IT system among the supply chain supports the collaborative approach by facilitating interaction among individuals, as well as the dissemination of information between different organisational levels (Myhr and Spekman, 2005). Smith et al. (2007) point out that the use of information technology can act as a facilitator for the development of supply chain collaboration. On the other hand, it can reduce some protective barriers around knowledge, assets and processes of the organisation. Therefore, the authors suggest that organisations need to learn how to deal with the increased exposition and risks inherent to the inter-connectivity and use of information technology.

\subsection{Joint planning}

By developing a joint planning, there is a trend that the supply chain members will balance their production processes, so that the probability of waste as well as high inventory levels is reduced (Cadilhon et al., 2005).

An example of joint planning that is frequently found in the literature is the collaborative planning, forecasting and replenishment (CPFR) initiative. Through the CPFR, business partners develop forecasts for production and demand together, and these forecasts are constantly updated based on real demand data and possible changes in the market (Stank et al., 2001).

\subsection{Processes documentation and standardisation}

Formalised processes and content of relations usually entails mutual agreement between the parties, reducing the chance of misunderstanding or ambiguities in the relationship (Kumar and VanDiesel, 1996; Stank et al., 2001). Stank et al. (2001) suggest that supply chain partners should identify the individual or group responsible for coordinating the operations along the supply chain and make this information available to all parties.

\subsection{Top management support}

With regard to top management, engagement, support and commitment is vital to the implementation of collaborative practices in the supply chain (Fawcett et al., 2006). Without this, efforts to an integrated approach between the actors in the supply chain can be superficial and ineffective. Moreover, managers need to 'sell' the idea of collaboration in the internal environment of their organisations (Stank et al., 2001), by investing in the propagation of a culture founded on teamwork (Fawcett et al., 2006). This is only possible if supported by top management. 


\subsection{Adoption of common objectives and goals}

It is necessary to pay attention to the following points when defining common objectives:

1 the organisations need to agree on the mission and vision for the alliance, so they can truly engage in the collaboration

2 the objectives of the collaboration must be aligned with the objectives of the organisations

3 individuals within organisations must also be aware and agree with the objectives of the collaboration (Pitsis et al., 2004).

Therefore, it is essential that the common objectives and goals be disseminated to all involved in the collaborative arrangement in the early stages of the partnership. If organisations do not adopt common objectives and goals, then the risk of self-interest behaviour increases and, thus, conflict with other partners may arise (Barratt, 2004b).

\subsection{Adoption of standard performance measurement model}

The supply chain members should define together a performance measure system, able to measure the individual performance of each part involved and also global performance of the supply chain as a whole (Simatupang and Sridharan, 2008). Different constituents of the supply chain will operate in different directions if the establishment of global measures is neglected (Barratt, 2004a). A performance measurement system usually consists of goals, metrics, lead-times and explicit mechanisms of performance feedback (Simatupang and Sridharan, 2008). Objectives should reflect the core value-adding tasks and objectives of the collaboration, e.g., customer service, quality, price and responsiveness. A logical map of cause and effect that describes how individual operations become customer value, is an example of how to develop and disseminate a standard performance measurement model (Simatupang and Sridharan, 2002).

\subsection{Cross-functional integration}

A collaborative environment among functional areas of the same organisation should be promoted, so that internal functional interdependence will subsequently expand beyond the boundaries of the firm, comprising the members of the supply chain (Min et al., 2005; Esper et al., 2010). In many cases, it is more difficult to promote integration within the company than between companies (Fawcett et al., 2006). In other words, sometimes it is be easier to establish collaboration between functional areas that perform similar roles in different organisations along the supply chain, than between different functional areas within one single organisation.

\subsection{Development and maintenance of close and long-term relationship}

The development and maintenance of close and long term relationships facilitates the formation of trustful relationships among the supply chain members (Mentzer et al., 2000). All the parties involved in the collaborative initiative need to realise the advantages and benefits it generates in order to develop and maintain long-term relationships (Kumar and VanDiesel, 1996; Lehoux et al., 2011). 


\subsection{Supply chain training}

An essential factor for the development of collaboration between supply chain members is the training and development of capabilities of individuals on issues concerning supply chain management (Barratt, 2004b). For example, Fawcett et al. (2008) developed an empirical research in order to examine the benefits, barriers and the driving forces behind the success of collaboration in supply chains, in which they found that companies must provide training and development of capabilities to their staff if they want them to adopt a collaborative attitude.

\section{A ladder to collaboration}

Achieving cooperation and coordination of supply chain activities will facilitate the development of collaborative practices in supply chains. Therefore, we propose a conceptual model for establishing cooperation, coordination and collaboration in supply chains, which is presented in Figure 1. Our conceptual model is developed as a ladder of three major steps. The first step consists of characteristics and behaviours required for a cooperative relationship. The second step comprises the requirements for coordination. Finally, the third step encompasses the characteristics and behaviour enablers of collaborative practices in supply chains.

The core constructs presented in Table 3 are the starting point for our model. As shown in Table 3, there is consensus that information sharing is required for establishing cooperative relationships (Spekman et al., 1998; Moharana et al., 2012). Besides this, Simatupang and Sridharan (2008) and Barratt (2004a) point out that information sharing provides the means for greater visibility, communication and transparency. The last characteristic of a cooperative relationship, interdependence, derives from common end and compliance.

In a cumulative process, in order to move from cooperation to coordination, therefore, to achieve higher level of integration, companies must keep the characteristics and behaviour present in cooperation and add new ones. From Table 3 we can identify two characteristics, flexibility and synchronised decision making, and two behaviours, investment in IT and joint planning. Moharana et al. (2012) highlights that coordination involves an interactive joint decision making process, which requires flexibility from supply chain partners.

However, in order to achieve joint planning, processes documentation and standardisation will play a key role reducing the chance of misunderstanding or ambiguities in the relationship (Kumar and VanDiesel, 1996; Stank et al., 2001). As important as processes documentation, it is the presence of a leader (leadership) (Pitsis et al., 2004; Mentzer et al., 2000). Finally, top management support can play a facilitator role for communication and information sharing in the cooperation, however, having in mind synchronised decision making and coordination of activities among different agents, to management support becomes crucial (Fawcett et al., 2006; Stank et al., 2001).

In addition to the characteristics and behaviours present in cooperation and coordination, collaboration will demand high levels of commitment, trust and organisational culture compatibility (Spekman et al., 1998; Moharana et al., 2012; Möller and Svahn, 2004). These are the characteristics that will underpin the behaviours required for collaboration we have identified from the literature. 
Figure 1 Ladder to collaboration

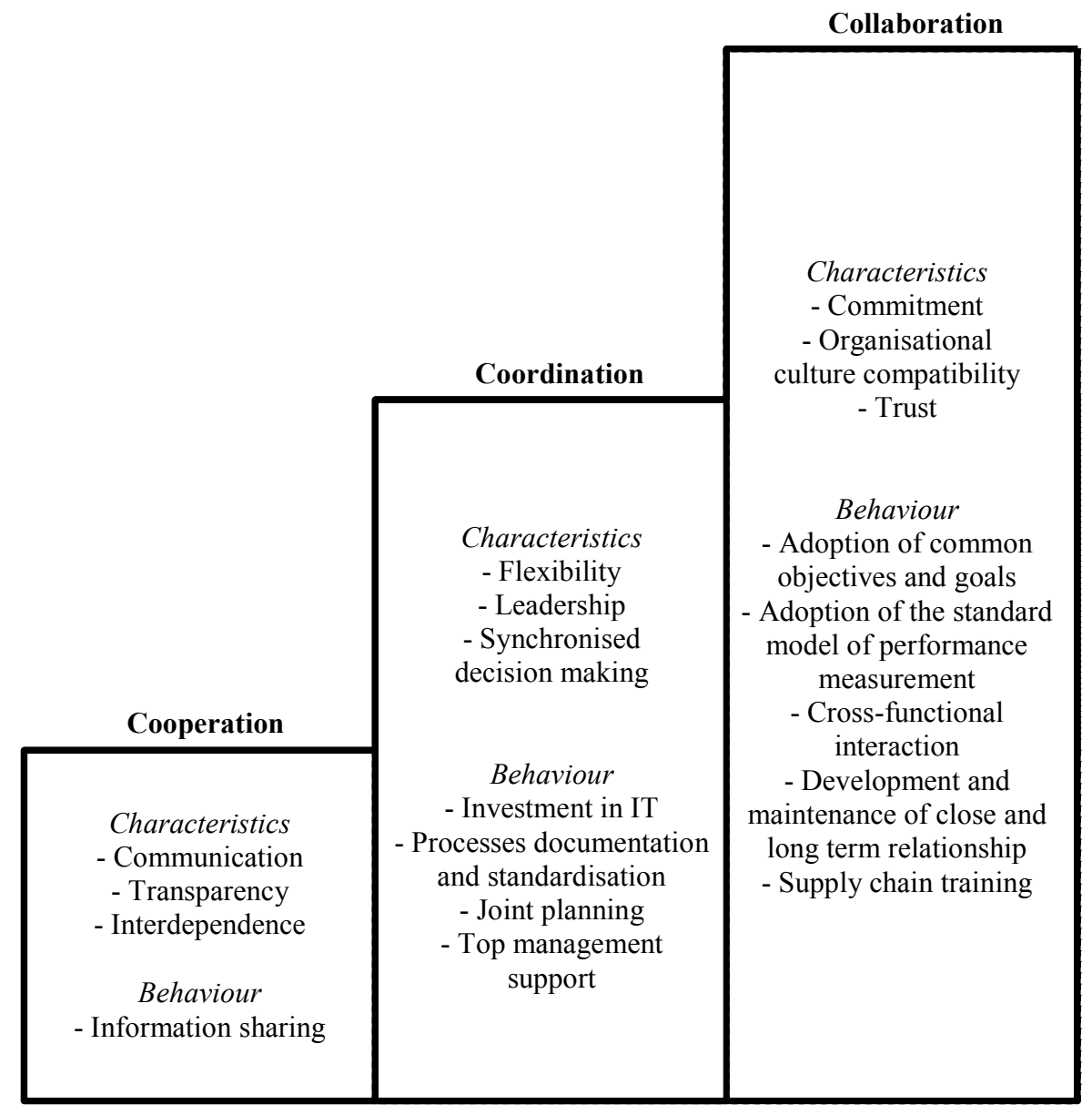

There are also a number of behaviours required for a collaborative supply chain. Taking the idea of collaboration as teamwork (Camarinha-Matos and Afsarmanesh, 2006; Bäckstrand, 2007; Moharana et al., 2012), the involved organisations need to have a certain level of organisational culture compatibility in order to make it feasible. Moreover, if it is teamwork, all the members of the team, which in our case are supply chain members, need to move towards the same direction. The adoption of common objectives and goals will pave the way for this (Spekman et al., 1998; Pitsis et al., 2004; Barratt, 2004b). Once goals and objectives have been defined, it is also important to set up a standard performance measurement model, which should evaluate the results individually and of the chain as a whole (Barratt, 2004a; Camarinha-Matos and Afsarmanesh, 2006; Simatupang and Sridharan, 2008).

Last but not least, supply chain training (Barratt, 2004b; Fawcett et al., 2008), cross-functional integration within the organisations (Min et al., 2005; Esper et al., 2010) and development and maintenance of close relationships (Kumar and VanDiesel, 1996; Mentzer et al., 2000; Lehoux et al., 2011) will also perform an important role in order to achieve the integration needed for a collaborative supply chain. 


\section{Conclusions, limitations and future research}

The aim of this study was to develop a conceptual model for establishing cooperation, coordination and collaboration in supply chains. The literature review brought out nine characteristics and ten behaviours typical of collaborative relationships and of organisations involved in this type of relationship, which were employed in order to build our ladder to collaboration model.

The proposed model consists of a step-by-step guide for achieving cooperation, coordination and collaboration in the supply chain. Such a model, unveiling each of these three levels of integration can contribute in two ways. Firstly, as a 'thermometer' to scale the level of effort in terms of characteristics and behaviours required from an organisation aiming to cooperate, coordinate and collaborate with supply chain members. Secondly, it contributes as a check-list for organisations in the process of integration.

On the other hand, the model presented in this paper remains untested. The characteristics and behaviours should be examined in future research. Therefore, we suggest an extension of this work by analysing the proposed model in field research. Finally, action-research within companies aiming at collaborative relationships would challenge our model and, potentially, provide data for enriching this theoretical development.

\section{References}

Ahuja, G. (2000) 'The duality of collaboration: inducements and opportunities in the formation of interfirm linkages', Strategic Management Journal, Vol. 21, No. 3, pp.317-343.

Akkermans, H. and VanDoremalen, J. (2004) 'Travail, transparency, and trust: a case study of computer-supported collaborative supply chain planning in high-tech electronics', European Journal of Operational Research, Vol. 153, No. 2, pp.445-457.

Bäckstrand, J. (2007) Levels of Interaction in Supply Chain Relations, Unpublished PhD thesis, Jönköping University, Göteborg, Sweden.

Barratt, M. (2004a) 'Understanding the meaning of collaboration in the supply chain', Supply Chain Management: An International Journal, Vol. 9, No. 1, pp.30-42.

Barratt, M. (2004b) 'Unveiling enablers and inhibitors of collaborative planning', International Journal of Logistics Management, Vol. 15, No. 1, pp.73-91.

Braziotis, C. and Tannock, J. (2011) 'Building the extended enterprise: key collaboration factors', The International Journal of Logistics Management, Vol. 22, No. 3, pp.349-372.

Cadilhon, J.J., Fearne, A.P., Tam, P.T.G., Moustier, P. and Poole, N.D. (2005) 'Collaborative commerce or just common sense? Insights from vegetable supply chains in Ho Chi Minh city', Supply Chain Management: An International Journal, Vol. 10, No. 3, pp.147-149.

Camarinha-Matos, L. and Afsarmanesh, H. (2006) 'Collaborative networks: value creation in a knowledge society' in Proceedings of PROLAMAT', 2006 IFIP International Conference on Knowledge Enterprise - New Challenges, China IFIP 207 Springer 2006, Shanghai, China, pp.1-14.

Cao, M. and Zhang, Q. (2011) 'Supply chain collaboration: impact on collaborative advantage and firm performance', Journal of Operations Management, Vol. 29, No. 3, pp.163-180.

Chen, I.J. and Paulraj, A. (2004) 'Understanding supply chain management: critical research and a theoretical framework', International Journal of Production Research, Vol. 42, No. 1, pp.131-163.

Christopher, M. and Peck, H. (2004) 'Building the resilient supply chain', The International Journal of Logistics Management, Vol. 15, No. 2, pp.1-13. 
Danese, P. (2007) 'Designing CPFR collaborations: insights from seven case studies', International Journal of Operations \& Production Management, Vol. 27, No. 2, pp.181-204.

Danese, P. (2011) 'Towards a contigency theory of collaborative planning initiatives in supply networks', International Journal of Production Research, Vol. 49, No. 4, pp.1081-1103.

Dyer, J.H. (1997) 'Effective interfirm collaboration: how firms minimize transaction costs and maximize transaction value', Strategic Management Journal, Vol. 18, No. 7, pp.535-556.

Esper, T.L., Defee, C.C. and Mentzer, J.T. (2010) 'A framework of supply chain orientation', International Journal of Logistics Management, Vol. 21, No. 2, pp.161-179.

Fawcett, S.E., Magnan, G.M. and Fawcett, A.M. (2010) 'Mitigating resisting forces to achieve the collaboration-enabled supply chain', Benchmarking: An International Journal, Vol. 17, No. 2, pp.269-293.

Fawcett, S.E., Magnan, G.M. and McCarter, M.W. (2008) 'Benefits, barriers, and bridges to effective supply chain management', Supply Chain Management: An International Journal, Vol. 13, No. 1, pp.35-48.

Fawcett, S.E., Ogden, J.A., Magnan, G.M. and Cooper, M.B. (2006) 'Organizational commitment and governance for supply chain success', International Journal of Physical Distribution \& Logistics Management, Vol. 36, No. 1, pp.22-35.

Fearne, A., Barrow, S. and Schulenberg, D. (2006) 'Implanting the benefits of buyer-supplier collaboration in the soft fruit sector', Supply Chain Management: An International Journal, Vol. 11, No. 1, pp.3-5.

Gaonkar, R. and Viswanadham, N. (2001) 'Collaboration and information sharing in global contract manufacturing networks', IEEE/ASME Transactions on Mechatronics, Vol. 6, No. 4, pp.366-376.

Hammervoll, T. and Bø, E. (2010) 'Shipper-carrier integration: overcoming the transparency problem through trust and collaboration', European Journal of Marketing, Vol. 44, Nos. 7/8, pp.1121-1139.

Handfield, R.B. and Bechtel, C. (2002) 'The role of trust and relationship structure in improving supply chain responsiveness', Industrial Marketing Management, Vol. 31, No. 4, pp.367-382.

Horvath, L. (2001) 'Collaboration: the key to value creation in supply chain management', Supply Chain Management: An International Journal, Vol. 6, No. 5, pp.205-207.

Kim, D. and Lee, R.P. (2010) 'Systems collaboration and strategic collaboration: their impacts on supply chain responsiveness and market performance', Decision Sciences, Vol. 41, No. 4, pp.955-981.

Kumar, K. and VanDiesel, H.G. (1996) 'Sustainable collaboration: managing conflict and cooperation in interorganizational systems', MIS Quarterly, Vol. 20, No. 3, pp.279-301.

Lee, Y.H., Wang, T. and Liu, C.H. (2011) 'Effects of virtual teams of supply chain collaboration on new product development', African Journal of Business Management, Vol. 5, No. 23, pp.9855-9870.

Lehoux, N., DAmours, S., Frein, Y., Langevin, A. and Penz, B. (2011) 'Collaboration for a two-echelon supply chain in the pulp and paper industry: the use of incentives to increase profit', Journal of the Operational Research Society, Vol. 62, No. 4, pp.581-592.

Lorentz, H. (2008) 'Collaboration in Finnish-Russian supply chains', Baltic Journal of Management, Vol. 3, No. 3, pp.246-265.

Matopoulos, A., Vlachopoulou, M., Manthou, V. and Manos, B. (2007) 'A conceptual framework for supply chain collaboration: empirical evidence from the agri-food industry', Supply Chain Management: An International Journal, Vol. 12, No. 3, pp.177-186.

Mentzer, J.T., Foggin, J.H. and Golicic, S.L. (2000) 'Collaboration: the enablers, impediments, and benefits', Supply Chain Management Review, Vol. 4, No. 4, pp.52-58.

Min, S., Roath, A.S., Daugherty, P.J., Genchev, S.E., Chen, H. and Arndt, A.D. (2005) 'Supply chain collaboration: what's happening?', International Journal of Logistics Management, Vol. 16, No. 2, pp.237-256. 
Moharana, H.S., Murty, J.S., Senapati, S.K. and Khuntia, K. (2012) 'Coordination, collaboration and integration for supply chain management', International Journal of Interscience Management Review, Vol. 2, No. 2, pp.46-50.

Möller, K. and Svahn, S. (2004) 'Crossing east-west boundaries: knowledge sharing in intercultural business networks', Industrial Marketing Management, Vol. 33, No. 3, pp.219-228.

Myhr, N. and Spekman, R.E. (2005) 'Collaborative supply-chain partnerships built upon trust and electronically mediated exchange', Journal of Business \& Industrial Marketing, Vol. 20, Nos. 4/5, pp.179-186.

Olorunniwo, F.O. and Li, X. (2010) 'Information sharing and collaboration practices in reverse logistics', Supply Chain Management: An International Journal, Vol. 15, No. 6, pp.454-462.

Pigatto, G. and Alcantara, R.L.C. (2007) 'Relacionamento colaborativo no canal de distribuição: uma matriz para análise', Gestão \& Produção, Vol. 14, No. 1, pp.167-177.

Piriyakul, M. (2011) 'A partial least squares model for SCM strategy, willingness for external collaboration, competitive performance and relative performance: effects of marketing and logistics performance in the palm oil industry', African Journal of Business Management, Vol. 5, No. 4, pp.1431-1440.

Pitsis, T.S., Kornberger, M. and Clegg, S. (2004) 'The art of managing relationships in interorganizational collaboration', Management, Vol. 7, No. 3, pp.47-67.

Pramatari, K. (2007) 'Collaborative supply chain practices and evolving technological approaches', Supply Chain Management: An International Journal, Vol. 12, No. 3, pp.210-220.

Sheu, C., Yen, H.R. and Chae, B. (2006) 'Determinants of supplier-retailer collaboration: evidence from an international study', International Journal of Operations \& Production Management, Vol. 26, No. 1, pp.24-49.

Simatupang, T.M. and Sridharan, R. (2002) 'The collaborative supply chain', International Journal of Logistics Management, Vol. 13, No. 1, pp.15-30.

Simatupang, T.M. and Sridharan, R. (2005) 'The collaboration index: a measure for supply chain collaboration', International Journal of Physical Distribution \& Logistics Management, Vol. 35, No. 1, pp.44-62.

Simatupang, T.M. and Sridharan, R. (2008) 'Design for supply chain collaboration', Business Process Management Journal, Vol. 14, No. 3, pp.401-418.

Singh, P.F. and Power, D. (2009) 'The nature and effectiveness of collaboration between firms, their customers and suppliers: a supply chain perspective', Supply Chain Management: An International Journal, Vol. 14, No. 3, pp.189-200.

Smith, G.E., Watson, K.J., Baker, W.H. and Pokorski II, J.A. (2007) 'A critical balance: collaboration and security in the IT-enabled supply chain', International Journal of Production Research, Vol. 45, No. 11, pp.2595-2613.

Spekman, R.E., Kamauff Jr., J.W. and Myhr, N. (1998) 'An empirical investigation into supply chain management: a perspective on partnerships', International Journal of Physical Distribution \& Logistics Management, Vol. 28, No. 8, pp.630-650.

Squire, B., Cousins, P.D., Lawson, B. and Brown, S. (2009) 'The effect of supplier manufacturing capabilities on buyer responsiveness: the role of collaboration', International Journal of Operations \& Production Management, Vol. 29, No. 8, pp.766-788.

Stank, T., Keller, S.B. and Daugherty, P.J. (2001) 'Supply chain collaboration and logistical service performance', Journal of Business Logistics, Vol. 22, No. 1, pp.29-48.

Taylor, D.H. and Fearne, A. (2006) 'Towards a framework for improvement in the management of demand in agri-food supply chains', Supply Chain Management: An International Journal, Vol. 11, No. 5, pp.379-384.

Tjosvold, D. (1988) 'Cooperative and competitive interdependence collaboration between departments to serve customers', Group and Organizations Studies, Vol. 13, No. 3, pp.274-289. 
Vereecke, A. and Muylle, S. (2006) 'Performance improvement through supply chain collaboration in Europe', International Journal of Operations \& Production Management, Vol. 26, No. 11, pp.1176-1198.

Vieira, J., Yoshizaki, H. and Ho, L. (2009a) 'Collaboration intensity in the Brazilian supermarket retail chain', Supply Chain Management: An International Journal, Vol. 14, No. 1, pp.11-21.

Vieira, J.G.V., Yoshizaki, H.T.Y. and Ho, L.L. (2009b) 'Um estudo sobre colaboração logística entre indústrias de bens de consumo e redes de varejo supermercadista', Gestão \& Produção, Vol. 16, No. 4, pp.556-570.

Vieira, J.G.V., Yoshizaki, H.T.Y. and Lustosa, L.J. (2010a) 'Os efeitos da colaboração na transação entre o fornecedor e o supermercado: um estudo exploratório', Produto \& Produção, Vol. 11, No. 3, pp.69-86.

Vieira, J.G.V., Yoshizaki, H.T.Y. and Lustosa, L.J. (2010b) 'Um estudo exploratório sobre colaboração logística em um grande varejo supermercadista', Produção, Vol. 20, No. 1, pp.135-147.

Yer, K.N.S. (2011) 'Demand chain collaboration and operational performance: role of IT analytic capability and environmental uncertainty', Journal of Business \& Industrial Marketing, Vol. 26, No. 2, pp.81-91. 